\title{
DNA barcoding and phylogenetic relationships of genera Picoides and Dendrocopos (Aves: Picidae)
}

\author{
Z.H. Huang' ${ }^{1}$ F.Y. Tu² and X.J. Liao' ${ }^{1}$ \\ ${ }^{1}$ School of Life Sciences, Jinggangshan University, Ji'an, Jiangxi Province, China \\ 2Jiangxi Academy of Forestry, Nanchang, Jiangxi Province, China \\ Corresponding author: Z.H. Huang \\ E-mail: hzhow@163.com \\ Genet. Mol. Res. 14 (4): 18370-18375 (2015) \\ Received August 14, 2015 \\ Accepted October 28, 2015 \\ Published December 23, 2015 \\ DOI http://dx.doi.org/10.4238/2015.December.23.24
}

ABSTRACT. Picoides and Dendrocopos are two closely related genera of woodpeckers (family Picidae), and members of these genera have long been the subjects of phylogenetic debate. Mitochondrial cytochrome c oxidase subunit I $(\mathrm{CO} /)$ is a powerful marker for the identification and phylogenetic study of animal species. In the present study, we analyzed the COI barcodes of 21 species from the two genera, and 222 variable sites were identified. Kimura two-parameter distances were calculated between barcodes. The average interspecific genetic distance was more than 20 times higher than the average intraspecific genetic distance. The neighbor-joining method was used to construct a phylogenetic tree, and all of the species could be discriminated by their distinct clades. Picoides arcticus was the first to split from the lineage, and the other species were grouped into two divergent clades. The results of this study indicated that the COI genetic data did not support the monophyly of Picoides and Dendrocopos.

Key words: Picoides; Dendrocopos; Phylogenetic relationship; DNA barcoding 


\section{INTRODUCTION}

The avian genera Picoides and Dendrocopos are the largest of the nearly worldwide family of woodpeckers (Picidae) (Short, 1982). The interpretation of the evolutionary relationship between Dendrocopos and Picoides has frequently changed (Rutkowski et al., 2006). Picidae is currently a conglomerate of two earlier genera of "pied" woodpeckers, Picoides (the "threetoed" woodpeckers) and Dendrocopos (the "ladder-backed" woodpeckers) (Weibel and Moore, 2002a). Therefore, Peters (1948) concluded that the original members of Picoides included only two species, $P$. tridactylus and $P$. arcticus, which both have a reduced hallux instead of the distinct fourth zygodactyl toe seen in Dendrocopos species. Delacour (1951) united the Dendrocopos and Picoides into the single genus Picoides according to priority in the systematic nomenclature, which claimed that variance in toe length or number is not phylogenetically important among closely allied avian species. Both genera were then combined into the single genus Picoides (Short, 1982). However, del Hoyo et al. (2003) surmised that "spotted" woodpeckers (Dendrocopos) should be separated from Picoides. Rutkowski et al. (2006) used the control region to resolve the phylogeny of the woodpecker family, and demonstrated that the three-toed woodpecker (Picoides) was grouped within a single monophyletic clade that included members of Dendrocopos. Thus, the systematics of the two genera isin need of revision.

Estimating phylogenies from DNA sequence data has become the major methodology of molecular phylogenetics (Prychitko and Moore, 2003). Large-scale standardized sequencing of mitochondrial cytochrome $\mathrm{c}$ oxidase subunit I $(\mathrm{CO} /)$ has made DNA barcoding an efficient tool for species identification in many animal groups (Hebert et al., 2003a,b). However, several studies have confirmed a clear gap (the so-called barcoding gap) between intra- and interspecific Kimura two-parameter (K2P) distance distributions (Breman et al., 2013). Previous barcoding studies on birds mainly focused on the surveys of regional groups, such as the Korean (Park et al., 2011), North American (Kerr et al., 2007), Southeast Asian (Lohman et al., 2009), Neotropical (Kerr et al., 2009b), and Scandinavian groups (Johnsen et al., 2010). Moreover, COI barcoding was successfully used to reconstruct the phylogenies of several animal groups at the family level (Cai et al., 2010; Huang and Ke, 2014, 2015). However, few DNA barcoding studies have been conducted at the genus level (Breman et al., 2013).

DNA barcoding studies on Picoides and Dendrocopos remain limited (Weibeland Moore, 2002a). In the present study, we examined a 652-bp COI fragment, and conducted phylogenetic analyses using sequences from Picoides and Dendrocopos. Our main aims were: 1) to test whether DNA barcodes allow the identification of Picoides and Dendrocopos species; and 2) to resolve the phylogeny of Picoides and Dendrocopos.

\section{MATERIAL AND METHODS}

Seventy-five COI sequences were obtained from GenBank, and 14 Picoides and 7 Dendrocopos species were analyzed (Table S1). COI sequences (652 bp) were aligned using Clustal X (Thompson et al., 1997). DnaSP v5.0 (Librado and Rozas, 2009) was used to define the variable sites, and sequence divergence among species and genera was calculated using the K2P (Kimura, 1980) distance model in MEGA 6.0 (Tamura et al., 2013). The neighbor-joining method (NJ) (Saitou and Nei, 1987) was used to reconstruct the phylogenetic tree (based the K2Pmodel) using MEGA6.0.Statistical support for the internodes in phylogenetic tree was tested by bootstrap percentages (BP) with 1000 replicates (Felsenstein 1985). 


\section{RESULTS}

\section{Barcoding analysis}

The 652-bp COI sequences were aligned, and the gene fragment corresponded to the Dryocopus pileatus mitochondrial gene that started at position 5456 and stopped at position 6107 (Gibb et al., 2007). Analyses were performed on 1 to 5 specimens per species (3.5 on average), and 222 variable sites were identified. Of these variable sites, 196 were parsimoniously informative (30.06\% of the entire sequence). All of the analyzed species had distinct $\mathrm{CO}$ sequences, and the average nucleotide composition was $24.04 \%$ T, $34.90 \%$ C, $24.74 \%$ A, and $16.32 \%$ G.

\section{Genetic distance}

\section{Picoides}

K2P within-species genetic distances had a small range (0 to $2.25 \%$ ), with more than $90.09 \%$ of the observations below a genetic distance of $1.00 \%$. Pairwise among-species comparisons were distributed from $2.02 \%$ (between $P$. nuttallii and $P$. scalaris) to $16.99 \%$ (between $P$. mixtus and $P$. arcticus). Most of the observed comparisons were between 7 to $16 \% \mathrm{~K} 2 \mathrm{P}$ genetic distance, and the K2P genetic distance peaked at $90.11 \%(\mathrm{~N}=91)$. The average interspecific genetic distance of the $\mathrm{COI}$ sequences $(10.82 \%)$ was 26 times higher than the average intraspecific genetic distance $(0.41 \%)$.

\section{Dendrocopos}

K2P within-species genetic distances ranged from $0.09 \%$ (D. major) to $1.13 \%$ (D. medius). Pairwise comparisons among-species varied from $4.06 \%$ (between $D$. leucotos and $D$. major) to $14.98 \%$ (between $D$. canicapillus and $D$. major). The average interspecific genetic distance of the $C O$ I sequences $(11.53 \%)$ was 22 times higher than the average intraspecific genetic distance $(0.51 \%)$.

\section{Phylogenetic relationships}

NJ was used to reconstruct the phylogenetic tree based on the K2P model, and Jynx torquilla was used as the outgroup. All of the species could be discriminated by their distinct clades (Fiqure S1). The black-backed woodpecker ( $P$. arcticus) was the first to split from the lineage $(\mathrm{BP}=$ $99 \%$, Fiqure S1), and the other species were grouped into two divergent clades ( $A$ and $B$, Fiqure S1).COI analysis strongly supported the placement of $P$. tridactylus with $P$. dorsalis in subclade $A_{1}$. The results of the $\mathrm{NJ}$ analysis suggested the inclusion of $D$. kizuki $+D$. maculatus $+D$.canicapillus in subclade $A_{2}$. Clade $B$ contained 15 species, including two subclades $\left(B_{1}\right.$ and $\left.B_{2}\right)$. Furthermore, $D$. medius, $D$. mahrattensis, $D$. leucotos, and $D$. major formed subclade $\mathrm{B}_{1}$. Clade $\mathrm{B}_{2}$ contained the other Picoides species $(P$. villosus $+P$. arizonae $+P$. albolarvatus $+P$. fumigatus $+P$. borealis, $P$. mixtus $+P$. lignarius $+P$. nuttallii $+P$. scalaris $+P$. minor $+P$. pubescens) Fiqure S1 $).$

\section{DISCUSSION}

The interspecific genetic distance of Picoides (2.02 to $16.99 \%$; average $10.82 \%$ ) and Dendrocopos (4.06 to $14.98 \%$; average $11.53 \%$ ) corresponded to COI genetic distances greater 
than $2.00 \%$, which is indicative of valid species (Hebert et al., 2003b). Several studies support the conclusion that distance-based DNA barcoding can provide sufficient information to identify and delineate a large majority of bird species (Kerr et al., 2007; Lohman et al., 2009; Kerr et al., 2009b; Johnsen et al., 2010; Park et al., 2011; Breman et al., 2013). Hebert et al. (2003a) proposed a "10X rule" to define species boundaries, which is defined as a sequence threshold that is 10 times the mean intraspecific variation ofthe group under study. However, the rate of COI gene evolution is subject to variation in different clades of birds (Pereira and Baker, 2006). Therefore, Huang and Ke (2015) postulated that it might be inappropriate to suggest a universal distance criterion for different species, and the Picoides and Dendrocopos results supported this opinion.

Mitochondrial DNA has been frequently used in woodpecker studies in order to resolve the phylogeny of the family, particularly the evolutionary relationships between Old and New World species (Weibeland Moore, 2002a; Winkler et al., 2005). The results of this study clearly showed the discriminative power of $\mathrm{COI}$ barcodes for the identification of Picoides and Dendrocopos species. Each woodpecker had distinct $C O I$ sequences, and the analysis separated the different species into distinct branches. Furthermore, none of the species shared sequences or exhibited overlapping clades with another species. The taxonomic position of the black-backed woodpecker was controversial (Winkler et al., 2005). In most cases, the black-backed woodpecker was considered to be the sister species of the Eurasian three-toed woodpecker ( $P$. tridactylus) (Weibel and Moore, 2002a). The surprising inference that the woodpecker was a basal lineage in the phylogeny was supported (Figure S1). Using cyt b, Winkler et al. (2005) also found that this species split off from the basal node. The evolutionary relationships deduced from our sequence data indicated that the black-backed woodpecker was likely a basal ancestor of Picoides and Dendrocopos. However, additional taxon sampling and different markers are needed to resolve the taxonomic status. The general topology of the phylogenetic tree was strongly supported; however, the $\mathrm{COI}$ analysis indicated that the two genera might be polyphyletic.

\section{Picoides}

Picoides is the most diverse genus within Picidae, and member species are found on most major land masses (Weibeland Moore, 2002a). Picoides has long been treated as a single group by most taxonomists. However, Weibel and Moore (2002a) concluded that Picoides was para phyletic with two related genera, Veniliornis and Dendropicos. Our results also supported the proposal that Picoides was not monophyletic. The COI phylogeny showed that Picoides species formed three distinct groups: $P$. arcticus, $P$. tridactylus $+P$. dorsalis, and the New World species. Several studies proposed that member species of New World Picoides were not monophyletic, because all analyzed Eurasian species were interspersed among the New World species (Short, 1971; Weibel and Moore, 2002a). The New World species formed three distinct subgroups: the "large" North American group ( $P$. villosus, $P$. arizonae, $P$. albolarvatus, $P$. fumigatus, and $P$. borealis), the South American group ( $P$. lignariusand $P$. mixtus), and the "small" North American group ( $P$. nuttallii, $P$. scalaris, and $P$. pubescens). It is important to note that the "small" North American group also included $P$. minor (a Eurasian species), and this result was consistent with the results of Weibeland Moore (2002a). The lesser spotted woodpecker (P. minor) was often placed in Dendrocopos (MacKinnon et al., 2000), and the smoky-brown woodpecker ( $P$. fumigatus) was merged intoVeniliornis. Although we did not include Veniliornis sequences, the results of this study supported the placement of the lesser spotted woodpecker and the smoky-brown woodpecker in Picoides. Moreover, Weibel and Moore (2002a,b) also placed the lesser spotted woodpecker within the Picoides. 


\section{Dendrocopos}

The systematic classification of Dendrocopos species was controversial. Dendrocopos was sometimes merged into Picoides, but this was neither generally accepted nor well supported. Our results indicated that monophyly of Dendrocopos was not supported. The NJ tree grouped members of Dendrocopos into two subclades, $\mathrm{A}_{2}$ and $\mathrm{B}_{1}$ (Figure S1). An interesting aspect of the phylogeny was the rather unexpected close relationship between the white-backed woodpecker (D. leucotos) and the great spotted woodpecker (D. major) (also see Weibel and Moore, 2002a; Winkler et al., 2005). The genetic distance between the two species was only $4.06 \%$. These two woodpeckers both occupy vast ranges, and they are sympatric, with the exception of some East Asian islands (Winkler et al., 2005). D. leucotos + D. major were sister taxa to $D$. medius $+D$. mahrattensis (Figure S1), which indicated that the white-backed woodpecker and the great spotted woodpecker should not be placed into the Picoides (however, see Weibel and Moore, 2002a,b). Weibel and Moore (2002b) found that $D$. leucotos $+D$. major grouped with $D$. fuscescens $+D$. griseocephalus. Moreover, some researchers also placed the white-backed woodpecker and the great spotted woodpecker within Dendrocopos (MacKinnon et al., 2000; Winkler et al., 2005).

\section{Conflicts of interest}

The authors declare no conflict of interest.

\section{ACKNOWLEDGMENTS}

Research supported by the National Natural Science Foundation of China (\#30960051, \#31260088, and \#31560590), the Jiangxi Province Talent Project “555”, Jiangxi Province Major Disciplines Academic Leaders (\#20133BCB22010), the Natural Science Foundation of Jiangxi Province (\#20132BAB204022, \#20152ACB21006), and the Science \& Technology Project of the Education Department of Jiangxi Province (\#GJJ10692).

\section{Supplementary material}

\section{REFERENCES}

Aliabadian M, Beentjes KK, Roselaar CS, van Brandwijk H, et al. (2013). DNA barcoding of Dutch birds. Zookeys 365: 25-48. Breman FC, Jordaens K, Sonet G, Nagy ZT, et al. (2013). DNA barcoding and evolutionary relationships in Accipiter Brisson, 1760 (Aves, Falconiformes: Accipitridae) with a focus on African and Eurasian representatives. J. Ornithol. 154: 265-87. Cai Y, Yue B, Jiang W, Xie S, et al. (2010). DNA barcoding on subsets of three families in Aves. Mitochondrial DNA 21: 132-137. DeFilippis VR and Moore WS (2000). Resolution of phylogenetic relationships among recently evolved species as a function of amount of DNA sequence: an empirical study based on woodpeckers (Aves: Picidae). Mol. Phylogenet. Evol. 16: 143-160.

del Hoyo J, Elliott AY and Christie D (2003). Handbook of the birds of the world volume 8: broadbills to tapaculos. Lynx Edicions. Delacour J (1951). The significance of the number of toes in some woodpeckers and kingfishers. Auk 68: 49-51.

Felsenstein J (1985). Confidence limits on phylogenies: an approach using the bootstrap. Evolution 39: 783-791.

Gibb GC, Kardailsky O, Kimball RT, Braun EL, et al. (2007). Mitochondrial genomes and avian phylogeny: complex characters and resolvability without explosive radiations. Mol. Biol. Evol. 24: 269-280.

Hebert PDN, Cywinska A, Ball SL and deWaard JR (2003b). Biological identifications through DNA barcodes. Proc. Biol. Sci. 270: 313-321.

Hebert PDN, Penton EH, Burns JM, Janzen DH, et al. (2004b). Ten species in one: DNA barcoding reveals cryptic species in the neotropical skipper butterfly Astraptes fulgerator. Proc. Natl. Acad. Sci. U. S. A. 101: 14812-14817. 
Hebert PDN, Ratnasingham S and deWaard JR (2003a). Barcoding animal life: cytochrome c oxidase subunit 1 divergences among closely related species. Proc. Biol. Sci. 270: S96-S99.

Hebert PDN, Stoeckle MY, Zemlak TS and Francis CM (2004a). Identification of birds through DNA barcodes. PLoS Biol. 2 : e 312. Huang ZH and Ke DH (2014). DNA barcoding and evolutionary relationships of the Phasianidae family in China. Genet. Mol. Res.13: 7411-7419.

Huang ZH and Ke DH (2015). DNA barcoding and phylogenetic relationships in Timaliidae. Genet. Mol. Res. 14: 5943-5949.

Johnsen A, Rindal E, Ericson PG, Zuccon D, et al. (2010). DNA barcoding of Scandinavian birds reveals divergent lineages in trans-Atlantic species. J. Ornithol. 151: 565-578.

Kerr KC, Lijtmaer DA, Barreira AS, Hebert PDH, et al. (2009a). Probing evolutionary patterns in neotropical birds through DNA barcodes. PLoS One 4: e4379.

Kerr KCR, Birks SM, Kalyakin MV, Red'kin YA, et al. (2009b). Filling the gap-COI barcode resolution in eastern Palearctic birds. Front. Zool. 6: 29.

Kerr KCR, Stoeckle MY, Dove CJ, Weigt LA, et al. (2007). Comprehensive DNA barcode coverage of North American birds. Mol. Ecol. Notes 7: 535-543.

Kerr KCR (2011). Searching for evidence of selection in avian DNA barcodes. Mol. Ecol. Resour. 11: 1045-1055.

Kimura M (1980). A simple method for estimating evolutionary rate of base substitutions though comparative studies of nucleotide sequences. J. Mol. Evol. 16: 111-120.

Librado P and Rozas J (2009). DnaSP v5: A software for comprehensive analysis of DNA polymorphism data. Bioinformatics 25: 1451-1452.

Lohman DJ, Prawiradiraga DM and Meier R (2009). Improved COI barcoding primers for Southeast Asian perching birds (Aves: Passeriformes). Mol. Ecol. Resour. 9: 37-40.

MacKinnon J, Phillipps K and He FQ (2000). A field guide to the birds of China. Hunan Education Publishing House.

Park HY, Yoo HS, Jung G and Kim CB (2011). New DNA barcodes for identification of Korean birds. Genes Genomics 33: 91-95.

Pereira SL and Baker AJ (2006). A molecular timescale for galliform birds accounting for uncertainty in time estimates and heterogeneity of rates of DNA substitutions across lineages and sites. Mol. Phylogenet. Evol. 38: 499-509.

Peters JL (1948). Check-list of birds of the world. Vol. 6. Harvard University Press, Cambridge.

Prychitko TM and Moore WS (2003). Alignment and phylogenetic analysis of beta-fibrinogen intron 7 sequences among avian orders reveal conserved regions within the intron. Mol. Biol. Evol. 20: 762-771.

Rutkowski R, Jagołkowska P, Mazgajski TD and Rejt $九$ (2006). A mitochondrial DNA control region phylogeny of the European woodpeckers Picidae. Genus 14: 173-176.

Saitou N and Nei M (1987). The neighbor-joining method: a new method for reconstruction phylogenetic trees. Mol. Biol. Evol. 4: 406-425.

Schindel DE, Stoeckle MY, Milensky C, Trizna M, et al. (2011). Project description: DNA barcodes of bird species in the National Museum of Natural History, Smithsonian Institution, USA. Zookeys 152: 87-92.

Short LL (1971). Systematics and behavior of some North American woodpeckers, genus Picoides (Aves). Bull. Am. Mus. Nat. Hist. 145: 1-118.

Short LL (1982). Woodpeckers of the world. Delaware Museum of Natural History, Greenville.

Tamura K, Stecher G, Peterson D, Filipski A, et al. (2013). MEGA6: molecular evolutionary genetics analysis version 6.0. Mol. Biol. Evol. 30: 2725-2729.

Thiemann TC, Brault AC, Ernest HB and Reisen WK (2012). Development of a high-throughput microsphere-based molecular assay to identify 15 common bloodmeal hosts of Culex mosquitoes. Mol. Ecol. Resour. 12: 238-246.

Thompson JD, Gibson TJ, Plewniak F, Jeanmougin F, et al. (1997). The CLUSTAL X windows interface flexible strategies for multiple sequence alignment aided by quality analysis tool. Nucleic Acids Res. 25: 4876-4882

Weibel AC and Moore WS (2002a). Molecular phylogeny of a group of cosmopolitan woodpeckers (genus Picoides) based on $\mathrm{COI}$ and cyt b mitochondrial gene sequences. Mol. Phylogenet. Evol. 22: 65-75.

Weibel AC and Moore WS (2002b). A test of a mitochondrial gene-based phylogeny of woodpeckers (genus Picoides) using an independent nuclear gene, beta-fibrinogen intron 7. Mol. Phylogenet. Evol. 22: 247-257.

Winkler H, Kotaka N, Gamauf A, Nittinger F, et al. (2005). On the phylogenetic position of the Okinawa woodpecker (Sapheopipo noguchii). J. Ornithol. 146: 103-110. 